\title{
DETEKSI KANGKER KULIT DENGAN MENGGUNAKAN METODE SUDUT HARRIS
}

\author{
Bahrun Niam ${ }^{1}$, Qirom $^{2}$, Dany Sucipto ${ }^{3}$ \\ Teknik Elektronika Politeknik Harapan Bersama Tegal \\ email: ${ }^{1}$ bahrun08@gmail.com, ${ }^{2}$ qirom.bahagia2@gmail.com, ${ }^{3}$ dany_sucipto@yahoo.com
}

\begin{abstract}
Ilmu pengetahuan dan teknologi sekarang mengalamai berkembangan yang sangat cepat. Seperti halnya ilmu pengetahuan dan teknologi, ilmu kedokteran juga berkembang sangan cepat terutama dalam bidang pengolahan citra dalam dalam mendiagnosa suatu penyakit. Salah satu aplikasi yang digunakan untuk pengolahan citra adalah mendeteksi kulit yang terkena penyakit kanker. Aplikasi yang digunakan adalah Deteksi Kangker Kulit Dengan Menggunakan Metode Sudut Harris. Gambar kulit yang terkena kangker kulit kemudian di rubah menjadi citra digital dengan cara discan. Kemudian citra kanker kulit dirubah kedalam bentuk citra grayscale dan proses selanjutnya yaitu deteksi sudut menggunakan metode sudut Harris. Gambar yang digunakan berjumlah 5 buah gambar kulit, dari kelima gambar kulit yang terkena penyakut kanker, semuanya bisa terdeteksi oleh aplikasi.
\end{abstract}

Keyword: sudut harris, kanker kulit, citra

\section{PENDAHULUAN}

Pada saat sekarang ini perkembangan ilmu pengetahuan dan teknologi semakin mengalami perkembangan dengan pesat. Sama halnya dengan perkembangan ilmu kedokteran yang diperlukan untuk mengetahui hasil dan meningkatkan kecepatan dan keakuratan penanganan medis terutama untuk mengidentifikasi suatu penyakit. Salah satu aplikasi yang di gunakan dalam pengolahan citra adalah mendeteksi kanker kulit.

Sebelumnya telah dilakukan penelitian kanker kulit dengan judul Deteksi Kanker Kulit Melanoma Berbasis Pengolahan Citra Menggunakan Wevelet Transform. Pengujian yang dilakukan terdiri dari pengujian terhadap parameter ektraksi ciri DWT, dan parameter klasifikasi KNN. Parameter terbaik dari pengujian sistem ini adalah menggunakan parameter filter DWT LL, kemudian menggunakan semua parameter fitur citra berupa mean, variance, dan standard deviation serta menggunakan nilai $\mathrm{K}=1$ pada $\mathrm{KNN}$. Sistem yang dibuat mendapatkan akurasi yang baik, yaitu $76 \%$. Dari penelitian sebelumnya, makan pada penelitian ini peneliti mengambil judul Deteksi Kangker Kulit Dengan Menggunakan Metode Sudut Harris.

Gambar kulit yang terkena kangker kemudian di rubah menjadi citra digital dengan cara discan. Setelah di scan citra kanker kulit kemudian dirubah ukurannya menjadi 200x300 pixels dengan cara cropping, kemudian citra kanker kulit dirubah kedalam bentuk citra grayscale dan proses selanjutnya yaitu deteksi sudut menggunakan metode sudut Harris.

\section{Tinjauan Pustaka}

\section{a. Kanker Kulit Melanoma}

Kanker kulit melanoma merupakan kanker kulit yang disebabkan olehpertumbuhan sel melanosit yang tidak terkontrol akibat kerusakan DNA.Melanoma adalah kanker kulit yang jarang ditemukan, namun lebih mematikan dibandingkan dengan jenis kanker kulit lain. Hal itu karena melanoma memiliki kemampuan metastasis ke organ lain yang lebih besar sehingga sebagian besar menyebabkan kematian pada kasus kanker kulit. Sebagian besar melanoma akan tetap memproduksi melanin, sehingga kanker kulit melanoma biasanya berwarna coklat atau hitam. Akan tetapi, ada juga yang tidak memproduksi melanin sehingga kanker kulit melanoma berwarna coklat, pink, atau putih (Rosidah, 2017).

Gambar 1 merupakan gambar perbandingan antara lapisan epidermis yang normal dan yang terdapat kanker kulit. Terlihat ada pertambahan jumlah sel skuamosa, sel basal, dan sel melanosit yang signifikan. Pertambahan jumlah sel skuamosa menyebabkan karsinoma sel skuamosa, pertambahan jumlah sel basal menyebabkan karsinoma sel basal, dan pertambahan jumlah sel melanosit menyebabkan kanker melanoma.

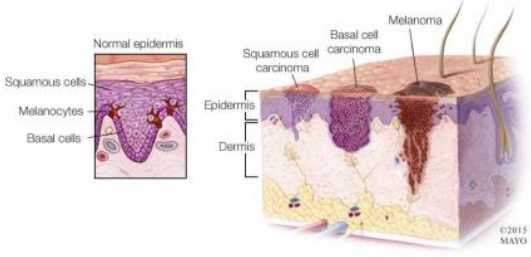

Gambar 1 Struktur Kulit yang terdapat Kanker.

\section{b. Citra Digital}

Secara umum, pengolahan citra digital menunjukan pada pemrosesan gambar dua dimensi menggunakan komputer. Dalam konteks yang lebih luas, pengolahan citra digital mengacu pada pemrosesan data dua dimensi. Citra digital merupakan sebuah larik (array) yang berisi nilai-nilai real maupun komplek yang direpresentasikan dengan deretan bit tertentu. (Darma, 2010).

Suatu citra dapan didefinisikan sebagai fungsi $\mathrm{f}(\mathrm{x}, \mathrm{y})$ berukuran $\mathrm{M}$ baris dan $\mathrm{N}$ kolom, dengan $\mathrm{x}$ dan $\mathrm{y}$ adalah koordinat spasial, dan amplitudo $\mathrm{f}$ di titik koordinat $(\mathrm{x}, \mathrm{y})$ dinamakan intensitas atau tingkat keabuan dari citra pada titik tersebut. Apabila nilai $\mathrm{x}, \mathrm{y}$ dan nilai amplitude f secara keseluruhan berhingga (finite) dan bernilai diskrit maka dapat dikatakan bahwa citra tersebut citra digital. Gambar 2 menunjukan posisi koordinat citra digital. (Darma, 2010). 


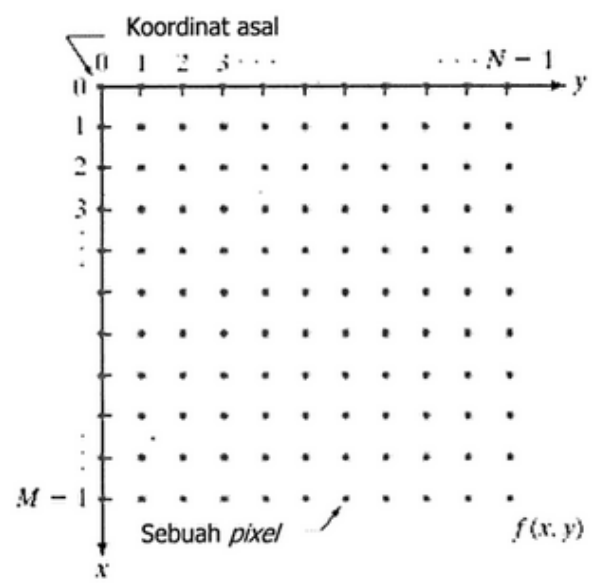

Gambar 2. Koordinat citra digital

\section{c. Grayscale}

Dilakukan proses grayscale untuk mengubah warna citra menjadi keabu- abuan. Grayscale merupakan citra digital yang hanya memiliki satu nilai kanal pada setiap pixelnya, dengan kata lain bagian Red $=$ Green $=$ Blue. Nilai tersebut digunakan untuk menunjukkan tingkat intensitas. Citra grayscale dibentuk dari 8 bit per informasi pixel dan menggunakan 256 bayangan warna abu-abu sebagai bagian dasar dari warna. Pada proses grayscale, masing-masing pixel RGB dari citra diambil nilainya, lalu dilakukan pengambilan mean dari ketiga nilai RGB tersebut, yang nantinya masingmasing nilai $\mathrm{R}, \mathrm{G}$, dan $\mathrm{B}$ akan diinisialisasi dengan nilai rata - ratanya tersebut sehingga tercipta warna keabu-abuan dari matriks citra yang telah dilakukan proses grayscale.(Candra., 2011).

\section{d. Sudut Harris (Harris Corner)}

Harris Corner adalah algoritma pendeteksi yang mempertimbangkan gradien lokal di arah horizontal dan vertikal setiap titik di sekitarnya. Tujuannya adalah untuk menemukan nilai di citra yang intensitasnya bervariasi di kedua arah tersebut.(Kartono and Alamsyah, 2012).

Pada pendeteksian sudut metode Harris, sudut didefinisikan sebagai pertemuan dua tepian. Oleh kerena itu, titik sudut tidak bisa didefinisikan pada piksel tunggal, karena disana hanya ada satu gradien setiap titik. Gradient adalah arah perubahan intensitas kecerahan dalam suatu citra seperti yang ditunjukan pada gambar 2.4.(Siswanto, 2013).

e. Persamaan tanggapan detector Harris dapat diperoleh dengan cara mengurangi determinan $\mathbf{M}$ dengan suatu konstanta sensitivitas dikalikan kuadrat trace M. seperti yang ditunjukan pada persamaan dibawah. (Siswanto, 2013).

$$
R_{H}=\operatorname{det}(M)-k * \operatorname{trace}^{2}(M)
$$

\section{Metode Penelitian}

Program deteksi kanker kulit menggunakan metode sudut Harris terdiri dari beberapa tahap seperti pada flowchart gambar dibawah ini.

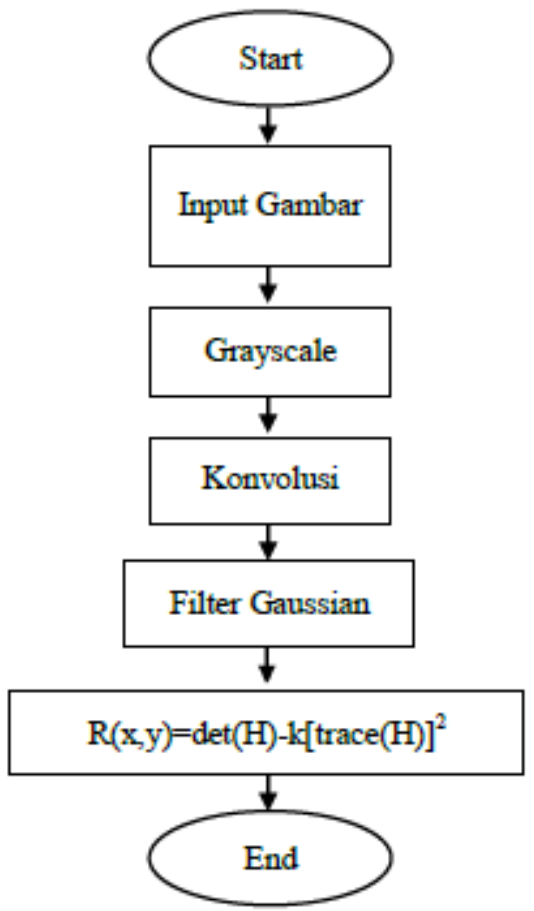

Gambar 3. Proses Deteksi Sudut Harris.

Gambar yang diinput merupakan gambar berwarna yang didapatkan dari proses pengumpulan data. Grayscale merupakan proses perubahan gambar dari gambar berwarna menjadi gambar aras keabuan. Proses selanjutnya yaitu deteksi kulit yang terkena kanker menggunakan metode deteksi sudut Harris. Pada proses deteksi sudut Harris, kulit yang tekena kanker kulit akan terdeteksi dengan menggunakan metode deteksi sudut Harris.

\section{Hasil Penelitian dan Pembahasan}

Tampilan modul Deteksi Kangker Kulit Dengan Menggunakan Metode Sudut Harris terdiri dari beberapa menu yaitu open image, grayscale, deteksi kanker, reset dan close.

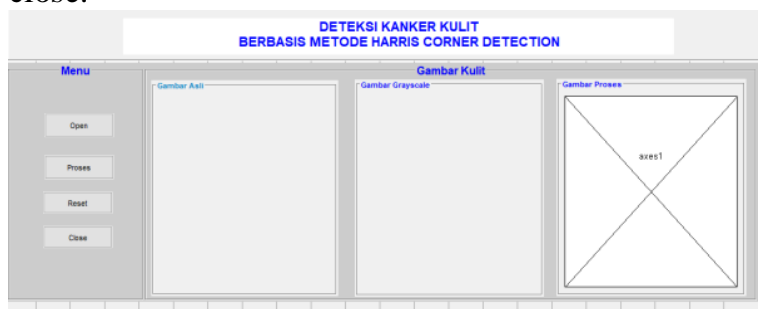

Gambar 4. Modul Deteksi Kanker Kulit

a. Open Image

Tombol open image berfungsi untuk mengambil gambar yang akan diproses. Gambar yang digunakan untuk penelitian yaitu Gambar1.jpg, Gambar2.jpg, Gambar3.jpg. Gambar4.jpg, Gambar5.jpg. Setelah gambar di pilih, selanjutnya gambar akan di tampilkan di menu gambar asli.

b. Grayscale

Tombol Grayscale berfungsi untuk merubah gambar asli yang masih gambar warna menjadi gambar aras keabuan.

c. Deteksi Kanker Kulit

Tombol deteksi Kanker Kulit berfungsi untuk 


\section{Daftar Pustaka}

gambar dengan tampilan tepi. Gambar deteksi Kanker Kulit merupakan gambar yang akan menunjukan gambar kulit tersebut terkena kanker kulit.

d. Reset

Tombol reset berfungsi untuk mengosongkan tampilan gambar atau mengganti gambar yang akan di proses.

e. Close

Tombol close berfungsi untuk menutup aplikasi.

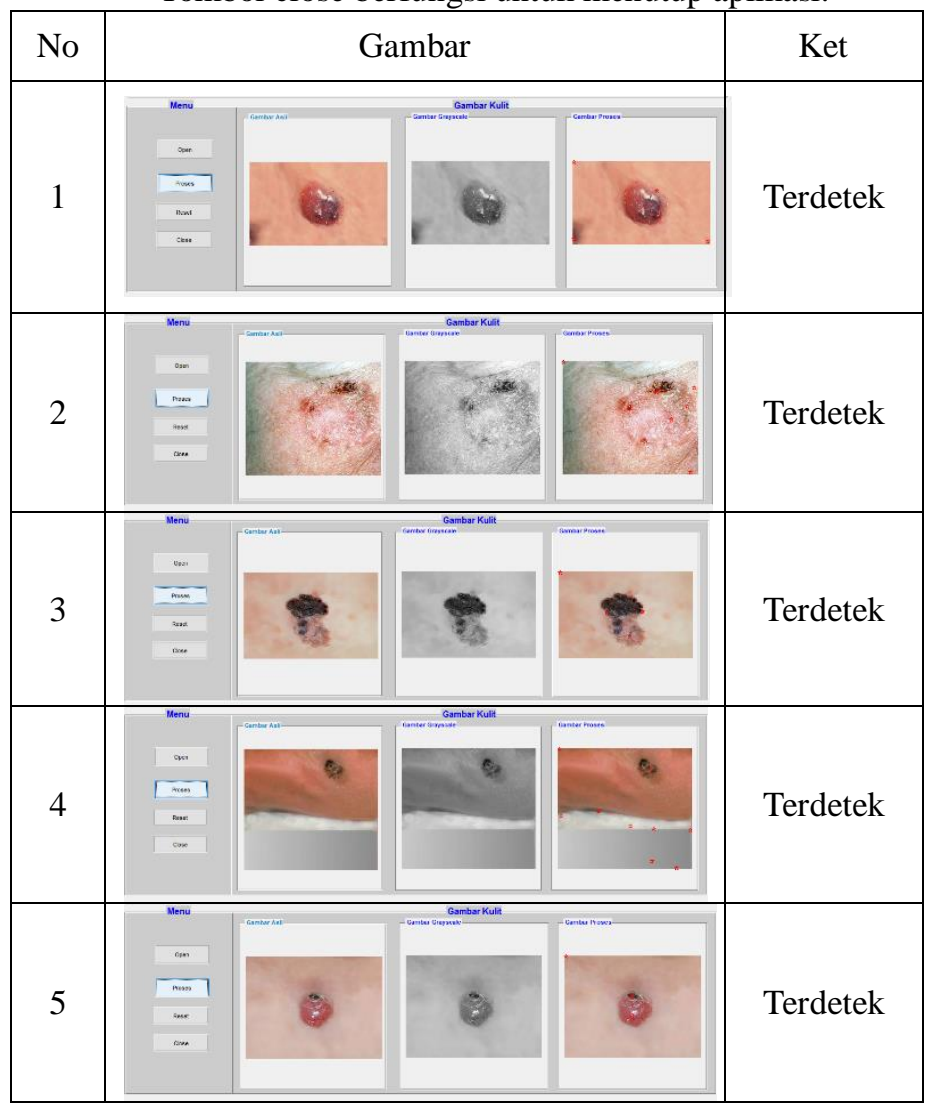

Pada tabel 4. merupakan hasil dari penelitian menggunakan metode Sudut Harris. Gambar yang digunakan berjumlah 5 buah gambar kulit, dari 5 gambar kulit yang terkena. Dari gambar kulit yang terkena kanker kulit terdeteksi kanker berjumlah 5 buah gambar kanker kulit.

\section{Kesimpulan}

1. Gambar yang digunakan untuk penelitian berjumlah lima gambar.

2. Gambar kanker kulit terdeteksi oleh metode sudut Harris.

3. Proses deteksinya yaitu, Pertama pilih gambar, kedua gambar RBG di rubah menjadi Grayscale, dan ketiga gambar di deteksi dengan metode Harris.
[1] Candra, R. et al. (2011) 'Mengubah Citra Berwarna Menjadi Gray - Scale dan Citra biner', 16(1), pp. 1419.

[2] Damayana Ikka. e-Proceeding of Engineering : Vol.3, No.3 December 2016

[3] Darma Putra. 2010. Pengolahan Citra Digital. Yogyakarta. Andi

[4] Kartono, A. and Alamsyah, D. (2012) 'Verifikasi Tanda Tangan Dengan Algoritma K-Nearest Neighbor dan Ekstraksi Ciri Harris Corner', (x).

[5] Citra Annisa: "Deteksi Tepi Citra Kanker Kulit Menggunakan Metode Laplacian of Gaussian". 2010.Universitas Negeri Syarif Hidayatullah Jakarta. 